\title{
The effects of different processing methods on the estimated nutritional value of rice bran according to the NRC-2001 Model $^{5}$ or DVE/OEB System ${ }^{6 *}$
}

\author{
Y. Wang ${ }^{1,2}$, H.S. Xin ${ }^{1}$, Y.Z. Li ${ }^{3}$, W.W. Zhang ${ }^{1}$, K. Xia ${ }^{1}$, Z.B. Wang ${ }^{1}$, \\ M. Li ${ }^{1}$ and Y.G. Zhang ${ }^{1,4}$ \\ ${ }^{1}$ College of Animal Science and Technology, Northeast Agricultural University \\ 150030 Harbin, P.R. China \\ ${ }^{2}$ College of Food and Biotechnolgy \\ Qiqihar University, 161006, P.R. China \\ ${ }^{3}$ West Central Research and Outreach Center, University of Minnesota \\ 56267 MN, USA
}

(Received 20 February 2012; revised version 30 July 2012; accepted 14 September 2012)

\begin{abstract}
Four dairy cows fitted with ruminal and T-shaped duodenal cannulas were used to investigate the effects of processing methods on the nutritional value of rice bran and to compare the potential nutrient supply according to the NRC-2001 model or the DVE/OEB system. Three different types of processed rice bran (puffed rice bran, PRB; expeller rice bran, ERB; solvent-extracted rice bran, $\mathrm{SRB}$ ) and unprocessed rice bran were chosen as materials. The results showed that the ERB and SRB protein concentrations were higher $(\mathrm{P}<0.05)$ than in unprocessed rice bran. According to the DVE/OEB system and the NRC-2001 model, the small intestine-absorbable protein contents (DVE or MP) in SRB and ERB were higher than in unprocessed rice bran $(\mathrm{RB})(\mathrm{P}<0.05)$. The nutritional values of rice bran were highly associated with the processing methods. The degraded protein balance (OEB) and the predicted absorbable small intestine protein (ASIP) using the NRC-2001 model were consistent with those using the DVE/OEB system.
\end{abstract}

KEY WORDS: rice bran, processing methods, nutritional value, DVE/OEB system, NRC-2001 model

\footnotetext{
* Supported by the FARA Project of the Agriculture Ministry in China

${ }^{4}$ Corresponding author: email: zhangyonggen@sina.com

Abbreviations: ${ }^{5} \mathrm{NRC}-2001$, Nutrient Requirements of Cattle-2001; ${ }^{6} \mathrm{DVE} / \mathrm{OEB}$, the Dutch Protein Evaluation System
} 


\section{INTRODUCTION}

Rice bran, a by-product of rice processing, is the cuticle between paddy husks. Removed rice bran is rich in protein, oil, vitamin $\mathrm{E}$, vitamin $\mathrm{C}$, beta-carotene, polyphenols, and oryzanol, and is high in calories; it is largely used as an ingredient in animal feeds. Despite the large production of rice by-products, limited research is available on their nutritive value, such as degradation characteristics, and on the application of rice bran in the ruminant industry (Foster et al., 1994). The high content of fat in rice bran hinders its storage, especially under tropical or subtropical conditions. In addition, feeding excessive fat to ruminants decreases fibre digestibility (Palmquist and Jenkins, 1980). Despite the use of defatting processing, which can improve the storage properties of rice bran, the energy content of rice bran inevitably decreases. Heating rice bran can prevent its rancidity because it inhibits the activity of lipase, but it may also cause the Maillard reaction (Zhao et al., 1996). With the rapid development of technology, producers and researchers have been striving to develop better methods to improve the nutritive value of rice bran. Various methods have been applied to optimize its use. Drying and steaming processing methods are widely used for stabilizing rice bran, and expeller and solvent-extracting methods are commonly used to separate oil from rice bran (Proctor and Bowen, 1996). Despite this, only a few studies have been conducted to determine the differences between different processed rice brans in terms of the nutritive value and potential nutrient supply to ruminants.

In this study, the nutritional values of differently processed rice bran were investigated. The specific objectives of this study were as follows: 1. to compare the chemical composition and rumen degradability of differently processed rice bran; 2 . to predict the nutrient supply to the small intestine of differently processed rice bran using the NRC model (2001) and the DVE/OEB system (Tamminga and Van Straalen, 1994), and 3. to determine the protein absorbable in the small intestine (ASIP) concentration and compare it with the predicted values using the NRC-2001 model and the DVE/OEB system.

\section{MATERIAL AND METHODS}

\section{Material}

In this study, the rice bran (RB) was processed via puffing, extracting, or expeller pressing to produce puffed rice bran (PRB), solvent-extracted rice bran (SRB), and expeller rice bran (ERB), respectively. Each kind of rice bran sample was collected from three different areas. To produce the puffed rice bran, fresh rice 
bran was put into an extruder and heated to $130^{\circ} \mathrm{C}$, and then ejected through small holes to make the puffed rice bran into certain lengths of loose small particles. The solvent-extracted rice bran was extracted at $85-95^{\circ} \mathrm{C}$ for $15 \mathrm{~min}$ in hexane to remove the oil from it, followed by centrifugation, and then the precipitate was dried into solvent-extracted rice bran meal. The expellering treatment involved feeding cracked rice bran into expeller presses with a central revolving shift. The pressure created by extruding extracted the oil mechanically from the rice bran; the temperature reached a maximum of $123^{\circ} \mathrm{C}$; the expelled rice bran was then cooled and dried. Samples and degraded samples analyzed for nutrient contents were ground to pass a 1-mm screen in a Wiley mill, and samples prior to rumen incubation were ground to pass a $2 \mathrm{~mm}$ screen in a Wiley mill.

\section{Animals and feeding}

Four dairy cows $(560 \pm 25 \mathrm{~kg})$ equipped with rumen cannulas (Bar Diamond, Parma, ID) and T-shaped duodenal cannulas were used for the in situ measurements of ruminal degradability and intestinal digestibility in sacco study. The procedures of ruminal and intestinal cannulation surgery and the experimental protocol were all approved by the Northeast Agricultural University Animal Science and Technology College Animal Care and Use Committee. The diet was formulated according to the NRC (2001). The ration was composited of roughage and concentrate at a ratio of $60: 40$. The ration was formulated with soyabean meal (7\% DM), cottonseed meal (4\% DM), cracked maize (21\% DM), wheat bran $(6 \% \mathrm{DM})$, maize silage $(60 \% \mathrm{DM})$, and premix $(2 \% \mathrm{DM})$ (including vitamin premix A, D and E, limestone, calcium hydrogen phosphate, and salt). Ruminal incubation in situ was carried out after the adaptation period. The cows were fed twice daily (8:00 am and 17:00 pm) and clean water was always available.

\section{Rumen incubation method}

The rice bran samples were incubated for $0,2,4,8,12,24$, and $48 \mathrm{~h}$, respectively. Two nylon bags of one time-point loaded with rice bran samples were placed in each cow at each period via a rumen cannula. Fifty-six nylon bags were used for each kind of processed RB. Ruminal degradation traits were determined using the method of Ørskov and McDonald (1979). The bags were inserted in reverse order of the incubation period so that they could all be removed at the same time (NRC, 2001). Each nylon-coded bag $(5 \mathrm{~cm} \times 7 \mathrm{~cm})$ with a pore size of approximately $50 \mu \mathrm{m}$ was loaded with $4 \mathrm{~g}$ of different processed RB. Before incubation, the bags were soaked in water $\left(39^{\circ} \mathrm{C}\right)$ for $20 \mathrm{~min}$, attached to a stainless-steel weight, and placed in the ventral sac of the 
rumen. Once the bags were removed from the rumen, they were immersed in 20-1 buckets containing cold water, then washed in an automatic washing machine $\left(5 \times 1\right.$-min wash, 2-min spin) until the rinse water was clear, and dried at $65^{\circ} \mathrm{C}$ for $48 \mathrm{~h}$.

\section{Chemical analysis}

Dry matter $(\mathrm{DM})$, ether extract $(\mathrm{EE})$, and crude protein $(\mathrm{CP})$ contents were analysed according to AOAC (1990) procedures. The analyses of neutral detergent fibre (NDF), acid detergent fibre (ADF), and acid detergent lignin (ADL) were performed according to the methods of Van Soest et al. (1991) using the Ankom system (Ankom 220 fibre analyzer; Ankom) with heat-stable $\alpha$-amylase and without sodium sulphite. Nitrogen fractions, defined according to the Cornell Net Carbohydrate and Protein System (CNCPS), were determined using the methods of Licitra et al. (1996). Starch was analysed using the anthrone shade selection method (Mc Donald and Henderson, 1964).

\section{Partitioning protein and carbohydrate fractions}

The $\mathrm{CP}$ and carbohydrate ( $\mathrm{CHO})$ fractions were partitioned according to the CNCPS (Sniffen et al., 1992). PA is the fraction of CP that was instantaneously solubilized at time zero. $\mathrm{PB}_{1}$ is the fraction of $\mathrm{CP}$ that was soluble in boratephosphate buffer and precipitated with trichloroacetic acid. $\mathrm{PB}_{2}$ is calculated as total $\mathrm{CP}$ minus the sum of fractions $\mathrm{PA}, \mathrm{PB}_{1}, \mathrm{~PB}_{3}$, and $\mathrm{PC} . \mathrm{PB}_{3}$ is calculated as the difference between the portions of total $\mathrm{CP}$ recovered with $\mathrm{NDF}$ and $\mathrm{ADF}$. $\mathrm{PC}$ is the fraction of $\mathrm{CP}$ recovered with $\mathrm{ADF}$ and is considered undegradable. PC contains proteins associated with lignins, tannins, and heat-damaged proteins, such as Mailard reaction products. $\mathrm{CA}$ is the fraction of total carbohydrate with a rapid $\mathrm{Kd}$ (degradation rate in $\left.\mathrm{h}^{-1}\right)\left(3 \mathrm{~h}^{-1}\right)$ and includes different kinds of sugars (fermentable soluble). $\mathrm{CB}_{1}$ is the fraction of total carbohydrate with an intermediate $\mathrm{Kd}(0.2-0.5$ $\mathrm{h}^{-1}$ ) and includes starch and pectin. $\mathrm{CB}_{2}$ is the fraction of total carbohydrate with a slow $\mathrm{Kd}\left(0.02-0.1 \mathrm{~h}^{-1}\right)$ and includes available cell walls. $\mathrm{CC}$ is the fraction of total carbohydrate that includes unavailable cell wall and cannot be fermented.

\section{Rumen degradation characteristics}

Rumen degradation characteristics of $\mathrm{CP}$ and starch were determined by the in sacco method. Then the results were calculated using the nonlinear regression model (NLIN) procedure of the statistical package of SAS (1999) using iterative least squares regression (Gauss-Newton method) by following the first-order kinetics equations: 


$$
\mathrm{R}(\mathrm{t})=\mathrm{U}+\mathrm{D} \times \exp \left(-\mathrm{Kd} \times\left(\mathrm{t}-\mathrm{T}_{0}\right) \text { for } \mathrm{CP}\right.
$$

and $\mathrm{R}(\mathrm{t})=\mathrm{D} \times \exp (-\mathrm{Kd} \times \mathrm{t})$ for starch (Ørskov and McDonald, 1979; Tamminga and Van Straalen, 1994),

where: $\mathrm{R}(\mathrm{t})$ stands for residue of the incubated material after $\mathrm{t} h$ of rumen incubation $(\mathrm{g} / \mathrm{kg})$; $\mathrm{U}$ and $\mathrm{D}$ stand for undegradable and potentially degradable fractions, respectively in $\mathrm{g} / \mathrm{kg}$; lag time $\left(\mathrm{T}_{0}\right)$ in $\mathrm{h}$; and the rate of degradation of fraction $\mathrm{D}(\mathrm{Kd})$ in $\mathrm{h}^{-1}$.

The effective degradability (ED) values were calculated as:

$$
\begin{aligned}
& \operatorname{EDCP}(\operatorname{EDST})(\mathrm{g} / \mathrm{kg})=\mathrm{S}+\mathrm{D} \times \mathrm{Kd} /(\mathrm{Kp}+\mathrm{Kd}) \\
& \operatorname{EDCP}(\mathrm{g} / \mathrm{kg} \mathrm{DM})=\mathrm{CP}(\mathrm{g} / \mathrm{kg} \mathrm{DM}) \times \operatorname{EDCP}(\mathrm{g} / \mathrm{kg}) \\
& \operatorname{EDST}(\mathrm{g} / \mathrm{kg} \mathrm{DM})=\mathrm{ST}(\mathrm{g} / \mathrm{kg} \mathrm{DM}) \times \operatorname{EDST}(\mathrm{g} / \mathrm{kg})
\end{aligned}
$$

where: the soluble fraction (S) is expressed in $\mathrm{g} / \mathrm{kg}$; ST stands for starch in $\mathrm{g} / \mathrm{kg}$ DM; EDCP and EDST stand for effective degradation rate of feed CP or starch in $\mathrm{g} / \mathrm{kg}$ or $\mathrm{g} / \mathrm{kg} \mathrm{DM}$; the passage rate $(\mathrm{Kp})$ of $0.06 \mathrm{~h}^{-1}$ is adopted from Tamminga and Van Straalen, 1994.

The rumen undegradable protein (RUP) values were calculated as:

$$
\begin{gathered}
\mathrm{RUP}(\mathrm{g} / \mathrm{kg})=\mathrm{U}+\mathrm{D} \times \mathrm{Kp} /(\mathrm{Kp}+\mathrm{Kd}) \\
\operatorname{RUP}(\mathrm{g} / \mathrm{kg} \mathrm{DM})=1.11 \times \mathrm{CP}(\mathrm{g} / \mathrm{kg} \mathrm{DM}) \times \mathrm{RUP}(\mathrm{g} / \mathrm{kg})
\end{gathered}
$$

where: the Kp of $0.06 \mathrm{~h}^{-1}$ is adopted (see above). The factor 1.11 in the formula is taken from the French PDI and Dutch DVE/OEB systems, and 1.11 was the regression coefficient of in vivo degradation data.

The rumen undegradable starch (RUST) values were calculated as:

$$
\begin{gathered}
\operatorname{RUST}(\mathrm{g} / \mathrm{kg})=\mathrm{D} \times \mathrm{Kp} /(\mathrm{Kp}+\mathrm{Kd})+0.1 \times \mathrm{S} \\
\operatorname{RUST}(\mathrm{g} / \mathrm{kg} \mathrm{DM})=\mathrm{ST}(\mathrm{g} / \mathrm{kg} \mathrm{DM}) \times \operatorname{RUST}(\mathrm{g} / \mathrm{kg})
\end{gathered}
$$

where: the $\mathrm{Kp}$ of $0.06 \mathrm{~h}^{-1}$ is adopted (see above). The factor 0.1 in the formula is adopted from an assumption that $100 \mathrm{~g} / \mathrm{kg}$ of soluble fraction (S) escapes from rumen fermentation for starch (Tamminga and Van Straalen, 1994).

Prediction of potential nutrient supply using the DVE/OEB system

Tamminga and Van Straalen (1994) provided the detailed concepts of the DVE/ OEB system. Yu and Meier (2003) provided a brief explanation of the potential nutrient supply.

Fermentable organic matter $(\mathrm{FOM})$ in the rumen was calculated as:

$$
\mathrm{FOM}=\mathrm{DOM}-\mathrm{EE}-\mathrm{RUP}-\mathrm{RUST}-\mathrm{FP}
$$


where: digested organic matter (DOM), EE, RUP and RUST are expressed in $\mathrm{g} / \mathrm{kg}$ $\mathrm{DM}$; Fermentation products (FP) are expressed just for conserved forages $(\mathrm{g} / \mathrm{kg}$ DM) (and assumed to be 'zero' for barley grain). Subsequently, microbial protein synthesized in the rumen based on available energy (E_MCP) was estimated as:

$$
\text { E_MCP }=0.15 \times \text { FOM }
$$

where: E_MCP in $\mathrm{g} / \mathrm{kg} \mathrm{DM}$, the factor 0.15 means that for every $\mathrm{kg}$ of rumen FOM, $150 \mathrm{~g}$ of microbial protein is assumed to be synthesized. True protein supplied to small intestine (TPSI) was calculated as:

$$
\text { TPSI }=\text { RUP }+0.75 \times \text { E_MCP }
$$

where: the factor 0.75 means that $750 \mathrm{~g} / \mathrm{kg}$ of microbial $\mathrm{N}$ is present in amino acids, and the remaining part of $\mathrm{N}$ is in nucleic acids.

True digestibility of microbial protein (MCP) is assumed to be $850 \mathrm{~g} / \mathrm{kg}$, and the amount of truly absorbable microbial protein in the small intestine (AMCP) was estimated as:

$$
\mathrm{AMCP}=0.85 \times 0.75 \times 0.15 \times \mathrm{FOM}
$$

where: AMCP is expressed in $\mathrm{g} / \mathrm{kg} \mathrm{DM}$.

Truly absorbable rumen undegradable protein in the small intestine (ARUP) was calculated as:

$$
\mathrm{ARUP}=\mathrm{RUP} \times \mathrm{d} \text { RUP, }
$$

where: digestibility of rumen undegradable protein in the small intestine (d RUP) is assumed to be $850 \mathrm{~g} / \mathrm{kg}$ (NRC, 2001).

According to the DVE/OEB system, $75 \mathrm{~g}$ of absorbable protein ( $\mathrm{kg} \mathrm{DM})$ in fecal excretion is required to compensate for endogenous losses. Endogenous protein in the small intestine (ENDP) was estimated as:

$$
\mathrm{ENDP}=75 \times \mathrm{UDM}
$$

where: undigested DM (UDM) and ENDP are expressed in $\mathrm{g} / \mathrm{kg} \mathrm{DM}$; $\mathrm{UDM}=$ undigested organic matter $(\mathrm{UOM})+$ undigested inorganic ash (UASH), where: $\mathrm{UOM}=\mathrm{OM}-\mathrm{DOM}, \mathrm{OM}$ stands for organic matter; $\mathrm{UASH}=\mathrm{ASH}-$ ASH $\times$ digestibility of inorganic matter $(\mathrm{d} \mathrm{ASH})$, where $\mathrm{d}$ ASH is assumed to be $650 \mathrm{~g} / \mathrm{kg}$.

The total truly digested protein in the small intestine (DVE, absorbable small intestine protein) value was estimated as:

$$
\mathrm{DVE}=\mathrm{ARUP}+\mathrm{AMCP}-\mathrm{ENDP}
$$

where: DVE is expressed in $\mathrm{g} / \mathrm{kg} \mathrm{DM}$. 
The degraded protein balance (OEB) value is the balance between microbial protein synthesis from rumen degradable $\mathrm{CP}$ and from the energy extracted during anaerobic fermentation in the rumen. The OEB value was estimated as:

$\mathrm{OEB}=$ nitrogen - microbial protein $\left(\mathrm{N} \_\mathrm{MCP}\right)-$ energy - microbial protein (E_MCP)

where: N_MCP $=\mathrm{CP}-\mathrm{RUP}=\mathrm{CP}-1.11 \times \mathrm{CP} \times \mathrm{RUP}$; E_MCP $=0.15 \times \mathrm{FOM}$; all parameters in $\mathrm{g} / \mathrm{kg} \mathrm{DM}$.

\section{Prediction of potential nutrient supply using the NRC-2001 model}

The detailed concepts and formulas were provided by NRC (2001). The following is a brief explanation.

Potential ruminally synthesized microbial $\mathrm{CP}(\mathrm{MCP})$ was calculated as:

$\mathrm{MCP}(\mathrm{g} / \mathrm{kg} \mathrm{DM})=0.13 \times$ total digest nutrient $(\mathrm{TDN})($ discounted$)$, when effective digestibility protein $(\mathrm{EDCP})$ exceeded $1.18 \times$ TDN-predicted MCP (MCP_TDN). When EDCP was less than $1.18 \times$ TDN-predicted MCP $(\mathrm{MCP}$ TDN), then MCP was calculated as 0.85 of EDCP (MCP_EDCP), where EDCP is expressed in $\mathrm{g} / \mathrm{kg} \mathrm{DM}$. The factor 0.13 means that $130 \mathrm{~g}$ of microbial protein is assumed to be synthesized for every kilogram of discounted TDN.

In the NRC model (2001), true protein and digestibility of ruminally synthesized microbial CP are assumed to be $800 \mathrm{~g} / \mathrm{kg}$. Therefore, the amount of truly absorbable MCP (AMCP) was estimated as:

$$
\mathrm{AMCP}=0.80 \times 0.80 \times \mathrm{MCP}
$$

where: AMCP is expressed in $\mathrm{g} / \mathrm{kg} \mathrm{DM}$.

Rumen endogenous CP (ECP), according to the NRC (2001), is calculated as:

$$
\mathrm{ECP}(\mathrm{g} / \mathrm{kg} \mathrm{DM})=6.25 \times 1.9 \times \mathrm{DM}(\mathrm{g} / \mathrm{kg}) .
$$

Assuming that $500 \mathrm{~g} / \mathrm{kg}$ of rumen endogenous $\mathrm{CP}$ passes into the duodenum and $800 \mathrm{~g} / \mathrm{kg}$ of rumen endogenous $\mathrm{CP}$ is true protein (NRC, 2001); the truly absorbable rumen endogenous protein in the small intestine (AECP) value was estimated as:

$$
\mathrm{AECP}=0.50 \times 0.80 \times \mathrm{ECP}
$$

where: AECP and ECP is expressed in $\mathrm{g} / \mathrm{kg} \mathrm{DM}$.

Total metabolizable protein (MP, absorbable small intestine protein) in the NRC (2001) model is contributed by: 1. ruminally undegradable feed CP (RUP); 2. ruminally synthesized microbial $\mathrm{CP}(\mathrm{MCP})$; and 3. rumen endogenous $\mathrm{CP}(\mathrm{ECP})$. Therefore, $\mathrm{MP}=\mathrm{ARUP}+\mathrm{AMCP}+\mathrm{AECP}$, where: $\mathrm{MP}$ is expressed in $\mathrm{g} / \mathrm{kg} \mathrm{DM}$. 
Based on data from NRC (2001), OEB (g/kg DM) reflects the difference between the potential microbial protein synthesis based on ruminally degradable feed CP (EDCP) and that based on energy (discounted TDN) available for microbial fermentation in the rumen, which was calculated as:

$\mathrm{OEB}=\mathrm{EDCP}-1.18 \mathrm{MCP} \_\mathrm{TDN}$ where: OEB is expressed in $\mathrm{g} / \mathrm{kg} \mathrm{DM}$.

Determining the absorbable small intestine protein concentration (ASIP) using the mobile nylon method

The same four cows were used to ruminally incubate additional RBs and estimate the intestinal digestibility of CP. The small intestine digestibility (SID) of RUP was determined using the method of Hvelplund (1985).

$$
\mathrm{ASIP}=\mathrm{MCP} \times 0.7+\mathrm{RUP} \times \mathrm{d} \mathrm{RUP}(\mathrm{MCP}=\mathrm{RUP} \times 0.9)
$$

where: d RUP - the small intestine digestibility of RUP (Feng and Lu, 2001).

\section{Statistical analysis}

Data were analysed using the randomized complete block design with the MIXED procedure of SAS (SAS, 1999). Using the feed and the cow as fixed and random effects, respectively, the following model was adopted:

$$
Y i j=u+F i+C j+E i j
$$

where: $\mathrm{Y}$ ij - the value of the variable studied on the Ith feed for the jth cow, $\mathrm{u}$ - the overall mean, $\mathrm{F} \mathrm{i}$ - the fixed effect of the ith feed $(\mathrm{i}=1-4), \mathrm{C} \mathrm{j}$ - the random effect of the jth cow $(j=1-4)$, and $E \mathrm{ij}$ - random error.

\section{RESULTS}

\section{Chemical composition of rice bran}

The chemical compositions of differently processed rice bran are presented in Table 1. The concentrations of EE in PRB, ERB, and SRB were lower $(\mathrm{P}<0.05)$, the $\mathrm{CP}$ concentrations of ERB and $\mathrm{SRB}$ were higher $(\mathrm{P}<0.05)$, and the starch concentration of $\mathrm{SRB}$ was $54 \mathrm{~g} / \mathrm{kg}$ higher than unprocessed rice bran $(\mathrm{P}<0.05)$. The ADF concentrations in processed RBs were lower $(\mathrm{P}<0.05)$ and $\mathrm{PRB}$ had the lowest ADF content among the treatments $(\mathrm{P}<0.05)$. The concentrations of NDF in ERB and SRB were significantly higher than those in $\mathrm{RB}(\mathrm{P}<0.05)$. The ERB and SRB had much lower ADL and soluble crude protein (SCP) contents and much higher neutral detergent insoluble crude protein (NDICP) and acid detergent insoluble crude protein (ADICP) contents than the other two rice brans $(\mathrm{P}<0.05)$. 
Table 1. Effect of different processing on chemical composition, protein and carbohydrate fractions of rice bran

\begin{tabular}{|c|c|c|c|c|c|}
\hline Composition & RB & PRB & ERB & SRB & SEM \\
\hline \multicolumn{6}{|c|}{ Chemical composition } \\
\hline EE, g/kg DM & $152^{\mathrm{a}}$ & $138^{\mathrm{b}}$ & $92^{\mathrm{c}}$ & $22^{\mathrm{d}}$ & 15.32 \\
\hline $\mathrm{CP}, \mathrm{g} / \mathrm{kg} \mathrm{DM}$ & $134^{\mathrm{c}}$ & $131^{\mathrm{c}}$ & $170^{\mathrm{b}}$ & $181^{\mathrm{a}}$ & 6.69 \\
\hline Starch, g/kg DM & $270^{\mathrm{b}}$ & $283^{\mathrm{b}}$ & $290^{\mathrm{b}}$ & $324^{\mathrm{a}}$ & 6.28 \\
\hline $\mathrm{ADF}, \mathrm{g} / \mathrm{kg} \mathrm{DM}$ & $133^{\mathrm{a}}$ & $76^{\mathrm{d}}$ & $115^{\mathrm{b}}$ & $98^{\mathrm{c}}$ & 6.59 \\
\hline NDF, g/kg DM & $309^{c}$ & $302^{\mathrm{c}}$ & $382^{\mathrm{a}}$ & $325^{\mathrm{b}}$ & 9.53 \\
\hline ADL, $g / \mathrm{kg}$ NDF & $52^{\mathrm{a}}$ & $51 \mathrm{a}$ & $23^{\mathrm{b}}$ & $25^{\mathrm{b}}$ & 4.16 \\
\hline SCP, g/kg CP & $292^{\mathrm{a}}$ & $298^{\mathrm{a}}$ & $160^{\mathrm{b}}$ & $146^{\mathrm{c}}$ & 21.49 \\
\hline NDICP, g/kg CP & $217^{\mathrm{c}}$ & $178^{\mathrm{d}}$ & $399^{\mathrm{a}}$ & $327^{\mathrm{b}}$ & 26.65 \\
\hline ADICP, g/kg CP & $16^{\mathrm{c}}$ & $26^{\mathrm{b}}$ & $30^{\mathrm{a}}$ & $27^{\mathrm{b}}$ & 1.62 \\
\hline \multicolumn{6}{|c|}{ Protein and carbohydrate fractions, CNCPS } \\
\hline $\mathrm{PA}, \mathrm{g} / \mathrm{kg} \mathrm{CP}$ & $246^{\mathrm{a}}$ & $247^{\mathrm{a}}$ & $157^{\mathrm{b}}$ & $142^{\mathrm{c}}$ & 14.73 \\
\hline $\mathrm{PB}_{1}, \mathrm{~g} / \mathrm{kg} \mathrm{CP}$ & $46^{\mathrm{b}}$ & $51^{\mathrm{a}}$ & $3^{c}$ & $4^{\mathrm{c}}$ & 6.83 \\
\hline $\mathrm{PB}_{2}, \mathrm{~g} / \mathrm{kg} \mathrm{CP}$ & $490^{b}$ & $524^{\mathrm{a}}$ & $455^{\mathrm{c}}$ & $527^{\mathrm{a}}$ & 9.13 \\
\hline $\mathrm{PB}_{3}, \mathrm{~g} / \mathrm{kg} \mathrm{CP}$ & $201^{\mathrm{c}}$ & $152^{\mathrm{d}}$ & $355^{\mathrm{a}}$ & $300^{\mathrm{b}}$ & 24.17 \\
\hline $\mathrm{PC}, \mathrm{g} / \mathrm{kg} \mathrm{CP}$ & $16^{\mathrm{c}}$ & $26^{\mathrm{b}}$ & $30^{\mathrm{a}}$ & $27^{\mathrm{b}}$ & 1.62 \\
\hline $\mathrm{CA}, \mathrm{g} / \mathrm{kg} \mathrm{CHO}$ & $277^{\mathrm{a}}$ & $284^{\mathrm{a}}$ & $209^{b}$ & $291^{\mathrm{a}}$ & 10.30 \\
\hline $\mathrm{CB}_{1}, \mathrm{~g} / \mathrm{kg} \mathrm{CHO}$ & $270^{\mathrm{b}}$ & $283^{b}$ & $290^{\mathrm{b}}$ & $324^{\mathrm{a}}$ & 6.28 \\
\hline $\mathrm{CB}_{2}, \mathrm{~g} / \mathrm{kg} \mathrm{CHO}$ & $391^{\mathrm{b}}$ & $376^{\mathrm{b}}$ & $468^{\mathrm{a}}$ & $357^{\mathrm{c}}$ & 12.82 \\
\hline $\mathrm{CC}, \mathrm{g} / \mathrm{kg} \mathrm{CHO}$ & $62^{\mathrm{a}}$ & $57^{\mathrm{b}}$ & $34^{\mathrm{c}}$ & $28^{\mathrm{d}}$ & 4.45 \\
\hline \multicolumn{6}{|c|}{$\begin{array}{l}\text { means with the same letter in the same raw are not significantly different }(\mathrm{P}>0.05) \text {; } \\
\text { SEM - standard error of mean; } \mathrm{RB} \text { - rice bran; } \mathrm{PRB} \text { - puffed rice bran; } \mathrm{SRB} \text { - solvent-extracted rice bran; } \\
\text { ERB - expeller rice bran; } \mathrm{EE} \text { - ether extract; } \mathrm{CP} \text { - crude protein; } \mathrm{ADF} \text { - acid detergent insoluble fibre; } \\
\text { NDF - neutral detergent fibre; } \mathrm{ADL} \text { - acid detergent lignin; } \mathrm{SCP} \text { - soluble crude protein; NDICP-neutral } \\
\text { detergent insoluble protein; } \mathrm{ADICP} \text { - acid neutral detergent insoluble protein; } \mathrm{PA} \text { - instantaneously } \\
\text { solubilized protein; } \mathrm{PB}_{1} \text { - rapidly degraded protein; } \mathrm{PB}_{2} \text { - intermediate degraded protein; } \mathrm{PB}_{3} \text { - slow } \\
\text { degraded protein; } \mathrm{PC} \text { - unavailable protein; } \mathrm{CA} \text {-rapid speed available carbohydrate; } \mathrm{CB}_{1} \text { - intermediate } \\
\text { speed available carbohydrate; } \mathrm{CB}_{2} \text { - slow speed available carbohydrate; } \mathrm{CC} \text { - unavailable carbohydrate }\end{array}$} \\
\hline
\end{tabular}

\section{Protein and carbohydrate fractions}

The processes of expelling and solvent-extracting could reduce the contents of $\mathrm{PA}$ and $\mathrm{PB}_{1}$ by $36.2-94.1 \%$, and these two methods also could increase the content of $\mathrm{PB}_{3}$ significantly, when compared with that in unprocessed $\mathrm{RB}(\mathrm{P}<0.05)$. The ERB had a much lower content of $\mathrm{PB}_{2}(455 \mathrm{~g} / \mathrm{kg} \mathrm{CP})$ than the other processed rice brans. Processing could also enhance the $\mathrm{PC}$ concentration of rice bran by more than 38\%. The concentration of CA in ERB was $209 \mathrm{~g} / \mathrm{kg} \mathrm{CHO,} \mathrm{which} \mathrm{was} \mathrm{much}$ lower than the other rice brans. The process of solvent-extracting made the content of $\mathrm{CB}_{1}$ much higher than in RB, PRB, and ERB. The ERB had the highest content of $\mathrm{CB}_{2}$, and $\mathrm{SRB}$ had the lowest $\mathrm{CB}_{2}$ content, while the other two kinds of rice bran were intermediate. Unprocessed rice bran had a much higher content of CC $(62 \mathrm{~g} / \mathrm{kg})$, suggesting different processing methods could significantly decrease the $\mathrm{CC}$ concentration of rice bran $(\mathrm{P}<0.05)$. 
In sacco rumen degradation traits

Rumen degradation characteristics of $\mathrm{CP}$ and starch in different kinds of rice brans are presented in Table 2. The unprocessed rice bran had the highest contents of soluble fraction (S) and unavailable protein (U), while it had the lowest content of the degradable fraction (D) and degradation rate $(\mathrm{Kd})$ among all the treatments. Increased RUP concentrations were found in ERB ( $77 \mathrm{~g} / \mathrm{kg} \mathrm{DM}), \mathrm{SRB}$ (77 g/kg DM), and PRB (66 g/kg DM). Puffed and expellered rice bran had lower contents of $\mathrm{D}$, however, these two processing methods enhanced the degradation rate of starch in rice bran. The three different processing methods lowered the contents of RUST (g/kg DM) and improved the contents of EDST (g/kg DM) in rice bran $(\mathrm{P}<0.05)$.

Table 2. Effect of different processing methods on rumen degradation characteristics of crude protein (using the Øskov model) and starch, using the DVE/OEB system

\begin{tabular}{lccccc}
\hline Degradation & $\mathrm{RB}$ & $\mathrm{PRB}$ & $\mathrm{ERB}$ & $\mathrm{SRB}$ & $\mathrm{SEM}$ \\
\hline In sacco rumen degradation characteristics & of crude protein & (using the & Øskov model) & \\
$\mathrm{S}, \mathrm{g} / \mathrm{kg}$ & $500^{\mathrm{a}}$ & $335^{\mathrm{c}}$ & $399^{\mathrm{b}}$ & $358^{\mathrm{c}}$ & 19.74 \\
$\mathrm{D}, \mathrm{g} / \mathrm{kg}$ & $261^{\mathrm{c}}$ & $487^{\mathrm{b}}$ & $468^{\mathrm{b}}$ & $553^{\mathrm{a}}$ & 33.33 \\
$\mathrm{U}, \mathrm{g} / \mathrm{kg}$ & $232^{\mathrm{a}}$ & $172^{\mathrm{b}}$ & $132^{\mathrm{c}}$ & $91^{\mathrm{d}}$ & 15.97 \\
$\mathrm{Kd}, \mathrm{h}^{-1}$ & $0.022^{\mathrm{b}}$ & $0.036^{\mathrm{a}}$ & $0.034^{\mathrm{a}}$ & $0.043^{\mathrm{a}}$ & 0.0026 \\
$\mathrm{RUCP}, \mathrm{g} / \mathrm{kg} \mathrm{DM}$ & $61^{\mathrm{c}}$ & $66^{\mathrm{b}}$ & $77^{\mathrm{a}}$ & $77^{\mathrm{a}}$ & 2.19 \\
$\mathrm{EDCP}, \mathrm{g} / \mathrm{kg} \mathrm{DM})$ & $73^{\mathrm{b}}$ & $65^{\mathrm{b}}$ & $93^{\mathrm{a}}$ & $104^{\mathrm{a}}$ & 4.82 \\
In sacco rumen degradation characteristics of & starch (using & the DVE/OEB & system) & \\
$\mathrm{S}, \mathrm{g} / \mathrm{kg}$ & $544^{\mathrm{b}}$ & $606^{\mathrm{a}}$ & $655^{\mathrm{a}}$ & $564^{\mathrm{b}}$ & 16.28 \\
$\mathrm{D}, \mathrm{g} / \mathrm{kg}$ & $455^{\mathrm{a}}$ & $393^{\mathrm{b}}$ & $334^{\mathrm{b}}$ & $436^{\mathrm{a}}$ & 16.28 \\
$\mathrm{Kd}, \mathrm{h}^{-1}$ & $0.031^{\mathrm{b}}$ & $0.067^{\mathrm{a}}$ & $0.069^{\mathrm{a}}$ & $0.054^{\mathrm{b}}$ & 0.006 \\
$\mathrm{RUST}, \mathrm{g} / \mathrm{kg} \mathrm{DM}$ & $76^{\mathrm{a}}$ & $47^{\mathrm{b}}$ & $41^{\mathrm{b}}$ & $69^{\mathrm{b}}$ & 4.55 \\
$\mathrm{EDST}, \mathrm{g} / \mathrm{kg} \mathrm{DM}$ & $194^{\mathrm{b}}$ & $236^{\mathrm{a}}$ & $249^{\mathrm{a}}$ & $255^{\mathrm{a}}$ & 8.63 \\
\hline
\end{tabular}

means with the same letter in the same raw are not significantly different $(\mathrm{P}>0.05)$; SEM - standard error of mean; RB - rice bran; PRB - puffed rice bran; SRB - solvent-extracted rice bran; ERB - expeller rice bran; $\mathrm{S}$ - soluble fraction; $\mathrm{D}$ - potentially degradable fractions; $\mathrm{U}$ - undegradable fractions; $\mathrm{kd}$ - degraded rate in in $\mathrm{h}^{-1}$; RUCP - rumen undegradable protein; EDCP -effective degradable protein; RUST - rumen undegradable starch; EDST - effective degradable starch

Predicted potential nutrient supply using the DVE/OEB system and the NRC-2001 model

The predicted potential nutrients supplied to the dairy cattle small intestine using the DVE/OEB system are presented in Table 3. The FOM contents in ERB and SRB were greater than those of the other two kinds of rice bran $(\mathrm{P}<0.05)$. There were no significant differences in the DOM content and the ENDP content among all the treatments. The TPSI contents in the processed RBs were much greater $(\mathrm{P}<0.05)$ than in unprocessed RB. Processed RB had a higher content of DVE 
Table 3. Prediction of the potential nutrient supply of different processing rice bran to dairy cattle using the DVE/OEB system and NRC-2001 dairy model

\begin{tabular}{lccccc}
\hline Degradation & RB & PRB & ERB & SRB & SEM \\
\hline DVE/OEB system to predict the potential nutrient & supply to & dairy cattle, g/kg DM & \\
FOM & $574^{\mathrm{c}}$ & $582^{\mathrm{c}}$ & $604^{\mathrm{b}}$ & $674^{\mathrm{a}}$ & 11.93 \\
DOM & 851 & 861 & 862 & 877 & 3.45 \\
RUP & $61^{\mathrm{c}}$ & $66^{\mathrm{b}}$ & $77^{\mathrm{a}}$ & $77^{\mathrm{a}}$ & 2.19 \\
ENDP & 6 & 6 & 5 & 4 & 0.34 \\
TPSI & $126^{\mathrm{d}}$ & $131^{\mathrm{c}}$ & $145^{\mathrm{b}}$ & $153^{\mathrm{a}}$ & 3.33 \\
DVE (ASIP) & $100^{\mathrm{d}}$ & $105^{\mathrm{c}}$ & $118^{\mathrm{b}}$ & $126^{\mathrm{a}}$ & 3.13 \\
E_MCP (based on FOM) & $86^{\mathrm{c}}$ & $87^{\mathrm{c}}$ & $91^{\mathrm{b}}$ & $101^{\mathrm{a}}$ & 1.79 \\
N_MCP & $73^{\mathrm{b}}$ & $65^{\mathrm{b}}$ & $93^{\mathrm{a}}$ & $104^{\mathrm{a}}$ & 4.82 \\
OEB & -13 & -22 & 3 & 2 & - \\
NRC-2001 model to predict the potential nutrient, & g/kg DM & & & \\
TDN & $881^{\mathrm{c}}$ & $888^{\mathrm{c}}$ & $914^{\mathrm{b}}$ & $945^{\mathrm{a}}$ & 7.66 \\
RUP & $61^{\mathrm{c}}$ & $66^{\mathrm{b}}$ & $77^{\mathrm{a}}$ & $77^{\mathrm{a}}$ & 2.19 \\
ECP & 11 & 11 & 11 & 11 & - \\
AECP & 4 & 4 & 4 & 4 & - \\
MP(ASIP) & $88^{\mathrm{c}}$ & $87^{\mathrm{c}}$ & $112^{\mathrm{b}}$ & $128^{\mathrm{a}}$ & 4.25 \\
E_MCP (MCP_TDN) & $115^{\mathrm{c}}$ & $115^{\mathrm{c}}$ & $119^{\mathrm{b}}$ & $123^{\mathrm{a}}$ & 0.10 \\
N_MCP (MCP_EDCP) & $62^{\mathrm{b}}$ & $56^{\mathrm{b}}$ & $79^{\mathrm{a}}$ & $80^{\mathrm{a}}$ & 4.10 \\
OEB & -53 & -60 & -40 & -35 & - \\
Mobile nylon methods for nutrient determination & & & & \\
SID, g/kg RUP & $693^{\mathrm{d}}$ & $852^{\mathrm{b}}$ & $778^{\mathrm{c}}$ & $921^{\mathrm{a}}$ & 25.70 \\
ASIP, g/kg DM & $90^{\mathrm{d}}$ & $95^{\mathrm{c}}$ & $118^{\mathrm{b}}$ & $136^{\mathrm{a}}$ & 5.62 \\
\hline
\end{tabular}

means with the same letter in the same raw are not significantly different ( $\mathrm{P}>0.05)$; SEM - standard error of mean; RB - rice bran; PRB - puffed rice bran; SRB - solvent-extracted rice bran; ERB - expeller rice bran; FOM - fermentable organic matter; DOM - digested organic matter; RUP rumen undegradable protein; ENDP - endogenous protein in the small intestine; TPSI - true protein supplied to small intestine; DVE - the total truly digested protein in the small intestine; E_MCP Energy_ Microbial protein; N_MCP - Nitrogen _ Microbial protein; TDN - total digest nutrients; ECP - endogenous protein in the small intestine; $\overline{A E C P}$ - absorbable endogenous protein in the small intestine; MP - total metabolizable protein; E_MCP (MCP_TDN) - the potential microbial protein synthesis based on energy (discounted TDN) available; $\bar{N} \_$MCP (MCP_EDCP) - the potential microbial protein synthesis based on ruminally degradable feed CP (EDCP); OEB - the potential microbial protein synthesis based on ruminally degradable feed CP (EDCP) and that based on energy (discounted TDN) available for microbial fermentation in the rumen; SID - small intestine digestibility; ASIP - absorbable small intestine protein

(which represents absorbable small intestine protein, ASIP) than unprocessed RB $(\mathrm{P}<0.05)$, whereas SRB had the highest concentration of DVE $(\mathrm{P}<0.05)$. As for the contents of E_MCP and N_MCP, solvent-extracting and expellering increased them to above the level in unprocessed $\mathrm{RB}(\mathrm{P}<0.05)$, whereas the content of $\mathrm{PRB}$ was similar to that in unprocessed RB. The OEB values (degradable protein balance) of SRB and ERB were $2 \mathrm{~g} / \mathrm{kg}$ DM and $3 \mathrm{~g} / \mathrm{kg}$ DM, respectively, showing that solvent-extracting and expeller processing could decrease $\mathrm{N}$ loss. Compared with unprocessed rice bran (-13 g/ $\mathrm{kg} \mathrm{DM})$, the OEB value of PRB was $-22 \mathrm{~g} / \mathrm{kg}$ 
DM, showing that PRB had more energy loss when MCP was synthesized.

The predicted results of the potential nutrients supplied to the small intestines of dairy cattle using the NRC dairy model (2001) are presented in Table 3. The concentrations of total digestible nutrients (TDN) in SRB and ERB were greater $(\mathrm{P}<0.05)$, when compared with that in unprocessed RB. The RUP content had a similar tendency with TDN within treatments. No matter which kind of rice bran, the ECP and AECP contents were $11 \mathrm{~g} / \mathrm{kg} \mathrm{DM}$ and $4 \mathrm{~g} / \mathrm{kg} \mathrm{DM}$, respectively. The processes of expellering and solvent-extracting could enhance MP (represent absorbable small intestine protein, ASIP) content to $27.3-34.1 \%$ more than in unprocessed $\mathrm{RB}(\mathrm{P}<0.05)$. The ERB and $\mathrm{SRB}$ had higher concentrations of E_MCP (MCP_TDN) and N_MCP (MCP_EDCP) than unprocessed rice bran $(\mathrm{P}<0.05)$, and $\mathrm{PRB}$ had a similar content as unprocessed RB in terms of $\mathrm{E} \_\mathrm{MCP}$ and N_MCP contents. The OEB values of SRB and ERB were almost $-3 \overline{5} \mathrm{~g} / \mathrm{kg}$ $\mathrm{DM}$ and $-40 \mathrm{~g} / \mathrm{kg}$ DM, respectively, indicating that SRB and ERB could largely synthesize MCP and avoid energy loss. Compared with unprocessed rice bran, however, (-53 g/ $\mathrm{kg} \mathrm{DM})$, the OEB value of PRB was $-60 \mathrm{~g} / \mathrm{kg} \mathrm{DM}$, indicating that PRB had a greater energy loss than unprocessed rice bran.

The determined contents of SID and ASIP in processed RB were higher than those in unprocessed $\mathrm{RB}$, with $\mathrm{SRB}$ having the highest level and $\mathrm{RB}$, the lowest $(\mathrm{P}<0.05)$.

As shown in Table 4, the unprocessed RB had a significantly higher predicted ASIP concentration using the DVE/OEB system than the result obtained using the mobile nylon bag method $(\mathrm{P}<0.05)$, and no significant difference was found in the obtained ASIP concentration in unprocessed RB between the NRC-2001 model and the mobile nylon bag method. The ASIP concentration obtained by the DVE/OEB system was at the highest level in PRB, that obtained by the NRC-2001 model was the lowest, while the determined ASIP concentration using the mobile nylon bag method was intermediate. No significant difference in ERB was observed between using the DVE/OEB system and the mobile nylon bag method, and the predicted value was lowered by $6.49 \mathrm{~g} / \mathrm{kg}$ when using the NRC2001 model $(\mathrm{P}<0.05)$. The SRB had a lower predicted ASIP concentration when

Table 4. Comparative analysis of determined absorbable small intestine protein (ASIP) concentration and predicted ASIP concentration

\begin{tabular}{lcccc}
\hline ASIP & $\begin{array}{c}\text { Calculated } \\
\text { value }\end{array}$ & $\begin{array}{c}\text { Predict value, } \\
\text { the DVE system }\end{array}$ & $\begin{array}{c}\text { Predict value, } \\
\text { the NRC model }\end{array}$ & SEM \\
\hline RB, g/kg DM & $90^{\mathrm{b}}$ & $101^{\mathrm{a}}$ & $88^{\mathrm{b}}$ & 2.14 \\
$\mathrm{PRB}, \mathrm{g} / \mathrm{kg} \mathrm{DM}$ & $95^{\mathrm{b}}$ & $105^{\mathrm{a}}$ & $87^{\mathrm{c}}$ & 2.64 \\
$\mathrm{ERB}, \mathrm{g} / \mathrm{kg} \mathrm{DM}$ & $119^{\mathrm{a}}$ & $118^{\mathrm{a}}$ & $112^{\mathrm{b}}$ & 1.34 \\
SRB, g/kg DM & $136^{\mathrm{a}}$ & $126^{\mathrm{b}}$ & $118^{\mathrm{c}}$ & 2.65 \\
\hline
\end{tabular}

means with the same letter in the same raw are not significantly different $(\mathrm{P}>0.05)$; SEM - standard error of mean; RB - rice bran; PRB - puffed rice bran; SRB - solvent-extracted rice bran; ERB -expeller rice bran 
using the DVE/OEB system and the NRC-2001 model than when using mobile nylon bag method $(\mathrm{P}<0.05)$. No matter which kind of processing was employed, the concentrations of ASIP of the rice brans were much higher when obtained by the DVE/OEB system than by the NRC-2001 model $(\mathrm{P}<0.05)$.

Based on the data of ASIP concentrations obtained by the three different methods, the correlation coefficients $\left(\mathrm{R}^{2}\right)$ among them were 0.9578 (DVE/OEB system vs mobile nylon method), 0.9442 (NRC-2001 model vs mobile nylon method) and 0.9127 (DVE/OEB system vs NRC-2001 model), respectively, as shown in Figures 1, 2, and 3.

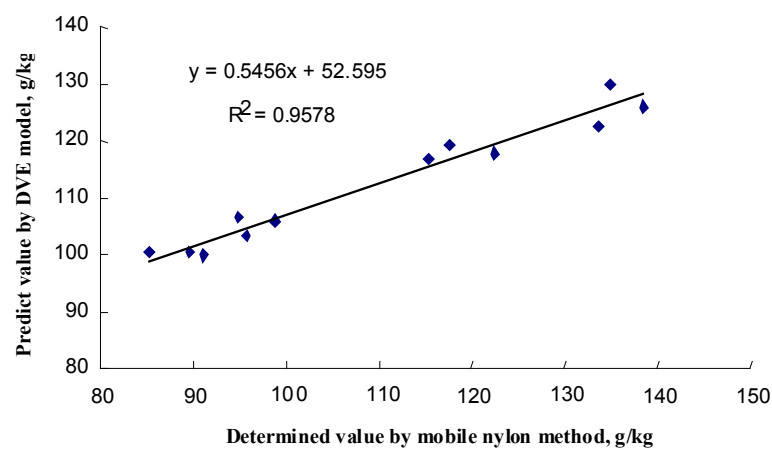

Figure 1. Correlation coefficient of predicted value using DVE system and determined value using mobile nylon bag method

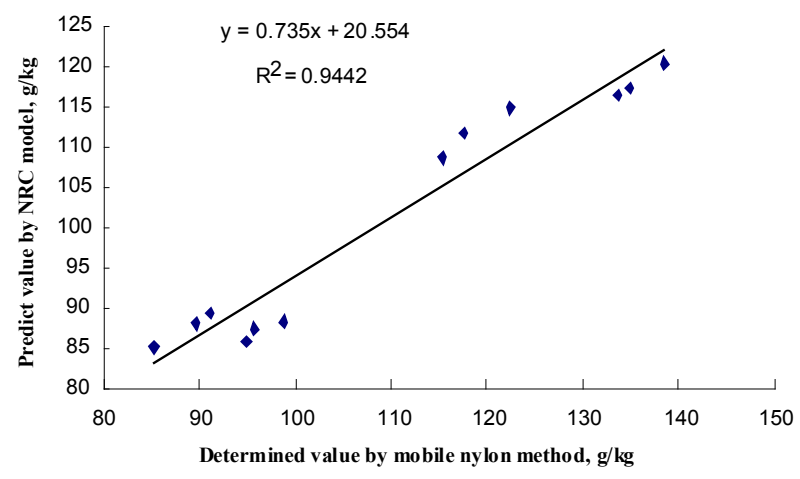

Figure 2. Correlation coefficient of predicted value using NRC system and determined value using mobile nylon bag method 


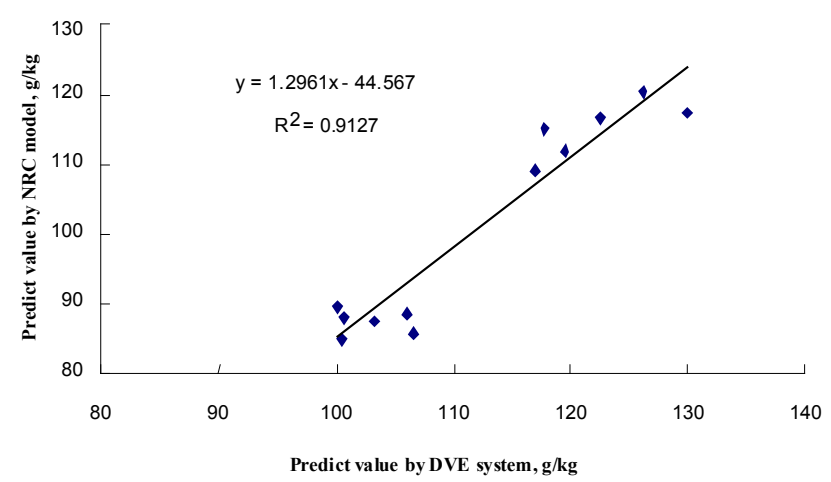

Figure 3. Correlation coefficient of predicted value using NRC system and DVE/OEB system

\section{DISCUSSION}

Comparative analysis of nutritional value in four kinds of rice bran

Foster et al. (1994) found that defatted rice bran had higher concentrations of $\mathrm{CP}$ and NDF than the full fat rice bran, which was in agreement with the results in our study. A similar impact of heat treatment on protein and fibre fractions was found in SBM (Demjanec et al., 1995). The concentrates of NDICP and ADICP in ERB and SRB were greater than those in unprocessed RB, which might be due to produced heat and chemical reactions during the processing (Demjanec et al., 1995). The increase in NDICP reflected an increase in the protein fraction that was slowly degraded in the rumen (Mustafa et al., 2000), whereas the increase in ADICP was an indication of increased heat-damaged protein, which would reduce protein digestibility (Can and Yilmaz, 2002). The soluble protein concentrations of ERB and PRB were lower than in unprocessed rice bran, which was due to heat denaturation during processing, resulting in reduced solubility of feed protein (Liu, 1999). In the current study, the concentrations of ADL of ERB and SRB were lower than those of unprocessed RB, which might be due to the high temperature, high pressure, and high shearing force generated in rice bran processing, resulting in a chemical bond split that could change heteropolarity and make unavailable fibre become available. The rapidly degraded protein (PA) in ERB and SRB decreased, indicating that the processing methods referred to might form combination structures of protein and fibre, preventing the protein from being rapidly degraded, which is consistent with the results of Anderson and Guraya (2001). The sum of $\mathrm{PB}_{1}, \mathrm{~PB}_{2}$, and $\mathrm{PB}_{3}$ concentrations is the true 
absorbable protein concentration (PB). The PB concentration increased when the rice bran was expeller processed and solvent-extracted. The $\mathrm{CC}$ concentration of processed RB decreased, showing that the available carbohydrate increased and the processed rice bran may have increased MCP (microbial protein) content.

The fraction $\mathrm{S}$ of $\mathrm{CP}$ was decreased and the fraction $\mathrm{D}$ of $\mathrm{CP}$ was increased in $\mathrm{PRB}, \mathrm{ERB}$, and $\mathrm{SRB}$, owing to the heating process, which is consistent with the results of Wang et al. (1997) in which heating decreased the soluble protein content and increased slow-degradable- and undegradable protein contents. The protein of rice bran underwent denaturation, racemization, and cross-linking reactions when the rice bran was heat-treated and defatted, rendering protein less susceptible to be microbial enzymes, leading to it being slowly degraded in the rumen (Wallace, 1994). Expeller and solvent-extracted processing decreased protein rumen degradability and increase bypass rumen protein content, which is similar to the results in an earlier report (Borucki et al., 2007). The EDST (g/kg DM) content was at a higher level for processed rice brans because of the breakdown of the adhesive properties of protein and starch during high temperature- and high pressure processing (McAllister et al., 1993). The synchronized increase in ammonia and energy in the rumen may increase MCP production, which prevents energy loss. Moreover, the efficiency of the synthesis of MCP increases with increasing speed of starch degradation (Hoover and Stroke, 1991). Sauvant and Milgen (1994) had also drawn the same conclusion, in which the replacement by rapidly degradable starch of slowly degradable starch could increase MCP production into the duodenum by $10 \%$.

Processing can increase the protein availability of rice bran, as shown in the present study. The tendency of the determined ASIP concentrations of different RBs using the mobile nylon method was similar with those seen using the two systems, as shown by comparative analysis of correlation coefficients. The ASIP concentration can be increased by the following three ways: 1. increasing feed protein concentration, 2. increasing RUP concentration, and 3. increasing RUP digestibility in the small intestine (NRC, 2001). The degrees of defatting od SRB and ERB were higher, and thus, the protein concentrations were greater and the heat and chemical reactions produced during the processing increased RUP concentrations and SID, thereby resulting in a higher concentration of ASIP being found in SRB and ERB.

Comparative analysis of the potential nutrient supply using the DVE/OEB system and the NRC-2001 model

In the DVE/OEB system, each feed has a DVE value that represents the true ASIP concentration. And each feed has a rumen degraded protein balance 
(called OEB in Dutch) value, which shows the balance of microbial synthesized protein based on the potentially rumen degradable protein and on the energy during ruminal fermentation. The NRC-2001 model introduces the concepts of MP, which represents the ASIP, and each feed also has the rumen degraded protein balance, which represents the difference between the potential synthesized microbial protein based on ruminally degraded feed CP and that based on TDN as energy available for microbial fermentation in the rumen.

In the DVE/OEB system, the DVE (ASIP) contents in SRB and ERB were greater than in unprocessed $\mathrm{RB}$, whereas $\mathrm{SRB}$ had the highest DVE content. In the NRC model, SRB and ERB had greater contents of MP $(\mathrm{P}<0.05)$ (ASIP) than that in unprocessed $\mathrm{RB}$, whereas SRB had the highest MP content, which was consistent with that in the DVE/OEB system. The OEB values of ERB and SRB were almost zero in the NRC-2001 model and DVE/OEB system, indicating that ERB and SRB had a potentially lower energy deficit in the rumen. The OEB values of PRB in the two systems were, however, far from zero compared with those of the unprocessed $\mathrm{RB}$, indicating that $\mathrm{PRB}$ had a greater energy deficit in the rumen, and PRB had a greater DVE content than unprocessed RB in DVE/OEB system, but no significant difference of MP was found between PRB and RB in the NRC model, which is owed to the different concepts used for the calculations on data from the two models. These results show that the potential nutrient supply was highly associated with the processing methods.

Comparative analysis of the determined ASIP (DVE, MP) using the mobile nylon method and the predicted ASIP using the DVE/OEB system and NRC-2001 model

The correlation coefficients $\left(\mathrm{R}^{2}\right)$ of predicted values using the two systems and determined value were higher than 0.9000 , respectively, indicating that the NRC-2001 model and the DVE/OEB system could predict the ASIP concentration. Comparative analysis using the correlation coefficients $\left(\mathrm{R}^{2}\right)$ showed that the effect of the predicted ASIP concentration using the DVE/OEB system was better than with the NRC-2001 model. In addition, the correlation coefficient $\left(\mathrm{R}^{2}\right)$ of the predicted ASIP concentrations using the DVE/OEB system and the NRC-2001 model was 0.9127, indicating that the predicted results using the NRC model were consistent with the DVE/OEB system. Yu et al. (2003) also found that the predicted values from the DVE/OEB system and the NRC-2001 model had significant correlations with high $\mathrm{R}^{2}(>0.9600)$ values, when these two systems were compared in predicting protein supply to dairy cows from selected forages. The consistencies were due to the similar principles of the predicted metabolizable protein values from the two models (Yu et al., 2003). 


\section{CONCLUSIONS}

The nutritional value, rumen degradability of rice bran, and intestinal digestibility were found to be highly influenced by different processing methods, and the processing could increase the absorbable small intestine protein concentration of rice bran. The degraded protein balance and the predicted absorbable small intestine protein (ASIP) values using the NRC-2001 model were consistent with those using the DVE/OEB system, which had better predicted function in ASIP concentration of rice bran.

\section{REFERENCES}

AOAC, 1990. Association of Official Analytical Chemists, Official Methods of Analysis. $15^{\text {th }}$ Edition. Washington, DC

Anderson A.K., Guraya H.S., 2001. Extractability of protein in physically processed rice bran. J. Amer. Oil Chem. Soc. 78, 969-972

Borucki Castro S.I., Phililp L.E., Lapierre H., Jardon P.W., Berthiaume R., 2007. Ruminal degradability and intestinal digestibility of protein and amino acid in treated soybean meal products. J. Dairy Sci. 90, 810-822

Can A., Yilmaz A., 2002. Usage of xylose or glucose as non-enzymatic browning agent for reducing ruminal protein degradation of soybean meal. Small Ruminant Res. 46, 173-178

Demjanec B., Merchen N.R., Cremin J.D., Aldrich C.G., Berger L.L., 1995. Effect of roasting on site and extent of digestion of soybean meal by sheep: I. Digestion and nitrogen and amino acids. J. Anim. Sci. 73, 824-834

Feng Y.L., Lu Z.N., 2001. Nutrient Requirement of Dairy Cattle and Feed Composition. China Agriculture Press. Beijing

Forster Jr. L.A., Goetsch A.L., Galloway Sr. D.L., Sun W., Patil A.R., Johnson Z.B., 1994. Digestion characteristics, feed intake and live weight gain by cattle consuming forage supplemented with defatted rice bran or other feedstuffs. Anim. Feed Sci. Tech. 47, 259-275

Hvelplund T., 1985. Digestibility of rumen microbial protein and undegraded dietary protein estimated in the small intestine of sheep and by in sacco procedure. Acta Agr. Scand. Sect. A. Anim. Sci. 25, 132-144

Hoover W.H., Stokes S.R., 1991. Balancing carbohydrates and protein for optimum rumen microbial yield. J. Dairy Sci. 74, 3630-3644

Licitra G., Hernandez T.M., Van Soest P.J., 1996. Standardization of procedures for nitrogen fraction of ruminant feeds. Anim. Feed Sci. Tech. 57, 347-358

Liu K., 1999. Chemistry and nutritional value of soybean components. In: Soybeans, Chemistry, Technology and Utilization. Aspen Publishers. Gaithersburg, MD, pp. 25-114

McAllister T.A., Phillippe R.C., Rode L.M., Cheng K.J., 1993. Effect of the protein matrix on the digestion of cereal grains by ruminal microorganisms. J. Anim. Sci. 71, 205-212

McDonald P., Henderson A.R., 1964. Determination of water soluble carbohydrate in grass. J. Sci. Food Agr. 15, 395-398

Mustafa A.F., Christensen D.A., McKinnon J.J., Newkirk R., 2000. Effects of stage of processing of canola seed on chemical composition and in vitro protein degradability of canola meal and intermediate products. J. Anim. Sci. 80, 211-214 
NRC, 2001. Nutrient Requirement of Dairy Cattle. National Research Council. $7^{\text {th }}$ revised Edition. National Academy Press, Washington, DC

Ørskov E.R., McDonald I., 1979. The estimation of protein degradability in the rumen from incubation measurements weighted according to the rate of passage. J. Agr. Sci. 92, 499-503

Palmquist D.L., Jenkins T.C., 1980. Fat in lactation rations: Review. J. Dairy Sci. 63, 1-14

Proctor A., Bowen D.J., 1996. Ambient-temperature extraction of rice bran oil with hexane and is opropanol. J. Amer. Chem. Oil Soc. 73, 811-813

SAS, 1999. User's Guide: Statistics, eighthed. SAS Institute Inc. Cary, NC

Sauvant D., Milgen J.V., 1994. Dynamica spects of carbohydrate and protein breakdown and the associated microbial matter synthesis. In: Ruminan Physiology: Digestion, Metabolism, Growth and Reproduction: Proceedings of the Eighth International Symposium on Ruminant Physiology. Willingen (Germany), pp. 25-30

Sniffen C.J., O’Connor J.D., Van Soest P.J., Fox D.G., Russell J.B., 1992. A net carbohydrate and protein system for evaluating cattle diets. II. Carbohydrate and protein availability. J. Anim. Sci. 70, 3562-3577

Tamminga S., Van Straalen W.M., 1994. The Dutch protein evaluation system: the DVE/OEB system. Livest. Prod. Sci. 40, 139-155

Van Soest P.J., Robertson J.B., Lewis B.A., 1991. Carbohydrate methodology, metabolism and nutritional implications in dairy cattle: Methods for dietary fiber, neutral detergent fiber and non-starch polysaccharides in relation to animal nutrition. J. Dairy Sci. 74, 3583-3597

Wallace R.J., 1994. Amino acid and protein synthesis, turnover, and breakdown by rumen microorganisms. In: Principles of Protein Metabolism in Ruminants. CRC Press, Boca Raton, F1, pp. 71-111

Wang Y., McAllister T.A., Zobell D.R., Pickard M.D., Xu Z., Rode L.M., Mir S., Cheng K.J., 1997. The effect of micronization of full-fat canola seed on digestion in the rumen and total tract of dairy cows. Can. J. Anim. Sci. 77, 431-440

Yu P., Christensen D.A., McKinnon J.J., 2003. Comparison of the National Research Council-2001 model with the Dutch system (DVE/OEB) in the prediction of nutrient supply to dairy cows from forages. J. Dairy Sci. 86, 2178-2192

Yu P., Meier J.A., 2003. Using the NRC-2001 model and the DVE/OEB system to evaluate nutritive values of Harrington (malting-type) and Valier (feed-type) barley for ruminants. Anim. Feed Sci. Tech. 107, 45-60

Zhao Y., Taniguchi K., Obitsu T., 1996. Effects of different processing procedures for rice bran on dietary nutrient digestion in each segment of the digestive tract of steers. Anim. Feed Sci. Tech. $59,265-277$ 